\title{
EXPRESS PREDICTION OF EXTERNAL DISTINCTIVE FEATURES OF PERSON USING THE PROGRAM OF DERMATOGLYPHICS FOR PREDICTION
}

\author{
Natalia Kozan \\ Department of Pathomorphology and Forensic Medicine \\ Ivano-Frankivsk National Medical University \\ 2 Galitska str., Ivano-Frankivsk, Ukraine, 76018 \\ Julia Kotsyubinskaya \\ Department of Pathomorphology and Forensic Medicine \\ Ivano-Frankivsk National Medical University \\ 2 Galitska str., Ivano-Frankivsk, Ukraine, 76018 \\ Galina Zelenchuk \\ Department of Pathomorphology and Forensic Medicine \\ Ivano-Frankivsk National Medical University \\ 2 Galitska str., Ivano-Frankivsk, Ukraine, 76018
}

\begin{abstract}
The aim of our study was to investigate the current state of computer identification applications, such as artificial neural networks. The material of our study were antroposcopic and anthropometric parameters obtained from 180 male and females aged 18-55 years living in the Ivano-Frankivsk region and belonging to Boiko, Lemko or Hutsul ethno-territorial group. Prints of comb pattern of the toes obtained by scanning with Futronic's FS80 USB2.0 Fingerprint Scanner using the program ftrScanApiEx.exe. followed by the transfer of data to a personal computer. For statistical processing of the obtained data we use STATISTICA 12 from the company StatSoft. Construction of neural networks was carried out using Neural Networks. As a result of our research there was carried out the prediction of anthropometric and antroposcopic parameters (ethno-territorial and gender belonging, etc.) through the use of dermatoglyphic parameters of the hands and feet in 180 people living in the Ivano-Frankivsk region. The proposed method allowed to obtain the results with a forecasts probability $73-90 \%$. The use of above algorithm of actions allowed a $50 \%$ increase of quality of identification of unknown person for using dermatoglyphic method and $67 \%$ facilitatation of the process of identification (of quantitative and qualitative calculations, determining correlations between parameters) in comparison with previously known manner. Therefore, our proposed method can be used as an express diagnostics of common phenotypic traits of the person (ethno-territorial affiliation, gender, etc.) at admission of mass victims (natural disasters, acts of terrorism, armed conflicts, man-made disasters, etc.), it doesn't not require a long time for conducting, specially trained staff and is inexpensive.Conclusions: The possibility of predicting external-recognizing features of a person such as etno-racial belonging, sex, anthropometric and antroposcopic parameters will allow widely use dermatoglyphic method at the level with other methods in conducting forensic identification of impersonal, fragmented and putrefactive modified corpses.
\end{abstract}

Keywords: Forensic Medicine, identification, dermatoglyphic parameters, artificial neural network, Program Dermatoglyphics for Prediction.

\section{Introduction}

Military conflicts in the world and in particular in Ukraine, lead to a large number of impersonal, fragmented and putrefactive modified corpses. Therefore, one of the topical issues of forensic medicine is the question posed by the problem of identification of an unknown person. At present, the most popular is DNA identification which is, despite the accuracy of the initial results, expensive method, time and funds - consuming, which implementation requires specially trained personnel. In this case, express method that can be used for identifying unknown person is dermatoglyphic method [1-3].

Dermatoglyphic method can have an appreciable advantage in determining relationship to other genetic methods. In particular, as a computer program, it can become widespread routine method of diagnosis in forensic medicine. Unfortunately, there are no similar programs for today. 
The closest analogues of this program can be dactyloscopic computer programs used in criminalistics for the purpose of automated identification of a fingerprint identity [4, 5]. Similar programs today already exist. At corresponding programmatic modifying, they probably could be useful in medical genetics and anthropology $[6,7]$.

In particular, Fokyn V. A. and co-author (2002), has created the program "KYBERINFORM" of medical genetic destination for analysis of main dermatoglyphics parameters which can serve as a complement to the programs which implemented their automatic identification, such as criminalistics dactyloscopic program "Songdo" (version 4.2 of "Pathfinder"), which has been widely used for forensic and criminalistic purposes since the early 90's and proved itself well. This program "Songdo" is capable, in particular, to automatically identify and classify basic types of papillary patterns of the terminal phalanges of both hands. Thus it differentiates the 19 types of such pictures and classifies them into arches, loops and curls on Galton-Henry system. The results of identification for each individual person can be seen on the computer screen. Making a start from these images can be possible to quantitatively estimate the degree of asymmetry of the right and left hands, to calculate the basic dermatoglyphic indicators for the control and experimental groups, that may be beneficial for mass population anthropometric and genetic research [8].

The last years artificial neural networks, on which base the identification program, including the forensic one was created, become increasingly popular $[9,10]$.

An artificial neural network (ANN) - a software-hardware complex, built on the mathematical model that resembles the principle of operation of biological neural networks. This concept formed the study of processes occurring in the brain [11, 12]. An artificial neural network (the neural network) is a system of connected and interacting processors (neurons). Neuron (basic neural network element) is a simple computer processor, which can handle, perceive and transmit simple signals (information). When you combine a large number of neurons in a network, the system can solve non-trivial task. Neural network is equally well appropriate for solving both linear and nonlinear problems. Neural network, depending on your architecture [13] can be divided by the level of difficulty. The basic type of neural network is a network of direct distribution - that is network that provides signals propagating only in one direction (for complex problems using recurrent neural network model). Neural networks have been widely applied in various types of complex problems needing analytical calculations of similar to those that the human's brain does. Among the major classes of problems for neural networks can be distinguished classification and prediction. The search and partition of the database on several parameters takes place at classification, at anticipation - the opportunity to provide some event or step for a given array of input data $[14,15]$.

The essence of the dermatoglyphic method of identifying unknown person is to use such resistant body parameters as picture comb of fingers and toes and hands and feet. These parameters are astonishingly informative. In humans, there are several dozen dermatoglyphic specific differences that can be used as diagnostic markers during forensic identification. Dermatoglyphic parameters have a highly individual and group variability, expressed polymorphism, and at the same time, the high level of inheritance. The complex of these properties determines the scope of the analysis for practical purposes: in genetics, anthropology, in criminology, and forensic medicine [16].

Dermatoglyphics is one of the most informative and convenient methods for the study of "complex appearance" of man, which contributes to its widespread use in forensic expertise practice in disputed paternity and identification of unknown person. The data indicate that the successful application of dermatoglyphics to identify an unknown person, along with other methods, can be regarded as a system of practices that effectively complement each other. Moreover, insufficient development, practical need, simplicity, and materially non-invasive non-burdensome character of the method determined the choice of digital palm and foot dermatoglyphics searching the criteria at diagnosis and markers of phenotype manifestations.

\section{Aim of research}

Investigate the current state of computer identification applications, such as artificial neural networks. 


\section{Materials and Methods}

The material of study were antroposcopic and anthropometric parameters obtained from 180 male and females aged 18-55 years living in the Ivano-Frankivsk region and belonging to Boiko, Lemko or Hutsul ethno-territorial group. Antroposcopic and anthropometric parameters were obtained as follows: a specially designed questionnaires included information on gender, age, ethnic and territorial affiliation, skin color, hair and eye shape and facial features, the forehead and frontal hillocks, eye shape, nose shape, cheekbones and lower jaw; anthropometric parameters (height, length of the foot and the hand, the length of the arms and legs, the length of trunk, the width of shoulders, transverse and longitudinal diameter of head, head circumference, height of forehead, height, upper and average width of face, cheekbones diameter, binomial width and height of nose) [17]. The dermatoglyphs of fingers and toes (180) obtained by scanning with Futronic's FS80 USB 2.0 Fingerprint Scanner using the program ftrScanApiEx.exe. with subsequent transfer of data to a PC and subsequent conversion of raster prints into vector graphic objects using the algorithm VeriFinger 6.6/MegaMatcher 4.4 Identification Technology Algorithm, which in future will facilitates quantitative and qualitative study of dermatoglyphic parameters of fingers and toes. Subsequently performed statistical analysis of the data by using the software package STATISTICA 10, along with other calculations determined the correlation between anthropometric and antroposcopic parameters (dermatoglyphics, ethno-regional and gender identity, etc.). The obtained results were used, developed by the authors of the program Dermatoglyphics For Prediction (DFP), built on artificial neural networks and GUI JAVA, for forecasting external recognizing features of a person [18].

\section{Result}

Neural networks can be used to predict the external-recognizing features of a person through the use of dermatoglyphic parameters [19]. There was developed several interrelated stages that make up the way of predicting external-recognizing features of a person. These steps are shown below.

Step 1: Building a neural network. To build the new neural network in the program STATISTICA simply type the appropriate input data to the table and choose the appropriate item from the menu Neural Networks (detailed instructions can be obtained by the reference) [20]).

Step 2.Training the neural network. For the purpose of training the neural network, except the input data (in this case dermatoglyphic parameters of hands and feet) (Al, LUl, Wr ..) it is necessary to add another category codes, namely - "train" for training and "select" the control subsample (Fig. 1).

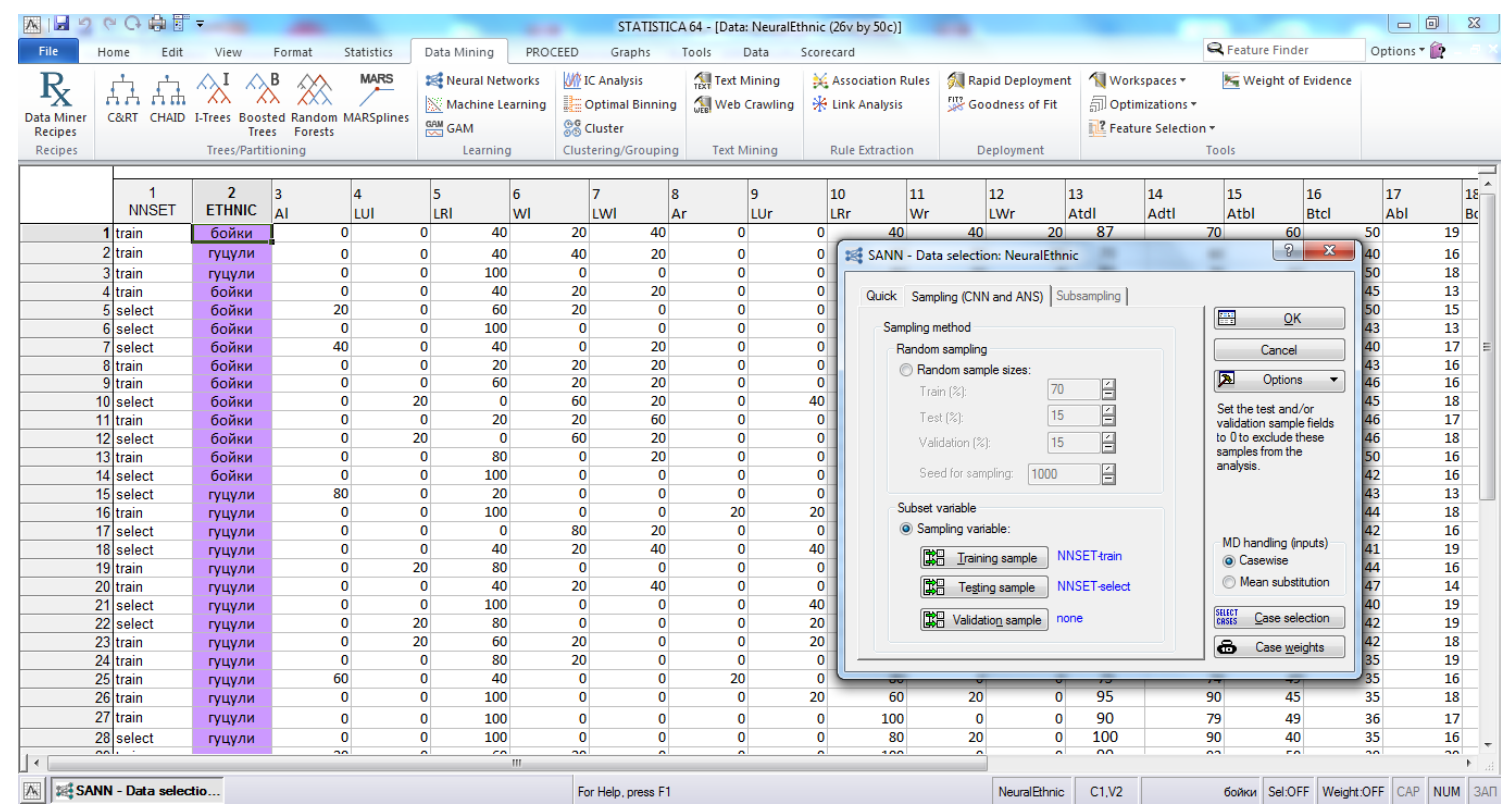

Fig. 1. Input data (left) and setting (right) for training the neural network 
As it is shown in the Fig. 1, except for the input data (Al, LUl, Wr), add another category codes, namely - "train" for training and "select" the control subsample. After you select the target category (in case, Ethnic) and continuous input variables (Al, LUl, Atdl), you have a choice between three strategies for building models (ANS - automated neural network, CNN custom neural network and Subsampling - of repeated sub-sample .For ease of implementation it is necessary to choose the automated neural network. With variable NNSET ask training (train) and control (select) set. Then choose the strategy for creation of sub-samples with the following input parameters: 5 random sub-samples with the relative percentage of 70-15-15\% - study - control subsample test. Choose the activation function Logistic, Tanh (logistic, hyperbolic,) for output neurons and Logistic, Tanh, Exponential (logistic, hyperbolic, exponent) for the hidden neurons. Also as output parameters indicates the number of hidden neurons - from 30 to 50, damped regularization of neurons weights (weight decay) - from 0.001 to 0.01 (for hidden layers), the number of networks for education - 20. All these data are experimentally selected and depending on the type and complexity of the tasks can vary into very wide limits, which will depend on the assigned tasks [21].

Step 3. Determining performance of the neural network. After the training 5 models of neural networks with different performance indicators (percentage of correct classification are received - the closer the number is to 100 , the better the model that classifies data), training and test performance.After receiving the initial results, you can select the network with a maximum capacity of training (in this case into the experimental network with the architecture MLP 24-42-3 (24 input, 42 hidden 3 output neurons).

If the result does not suit you (for example, the result of $85 \%$ is very low), then refine results by going to the model of CNN, which can be set for specifying input data - namely, the type of network RBF (radial basis functions), 20 networks for education, the number of neurons 50, the number of periods 10,000 is on interactive learning, to conduct visual analysis of errors. Such operations can be carried out until such time as the test performance and performance of training satisfy us, according to the data productivity (Fig. 2).

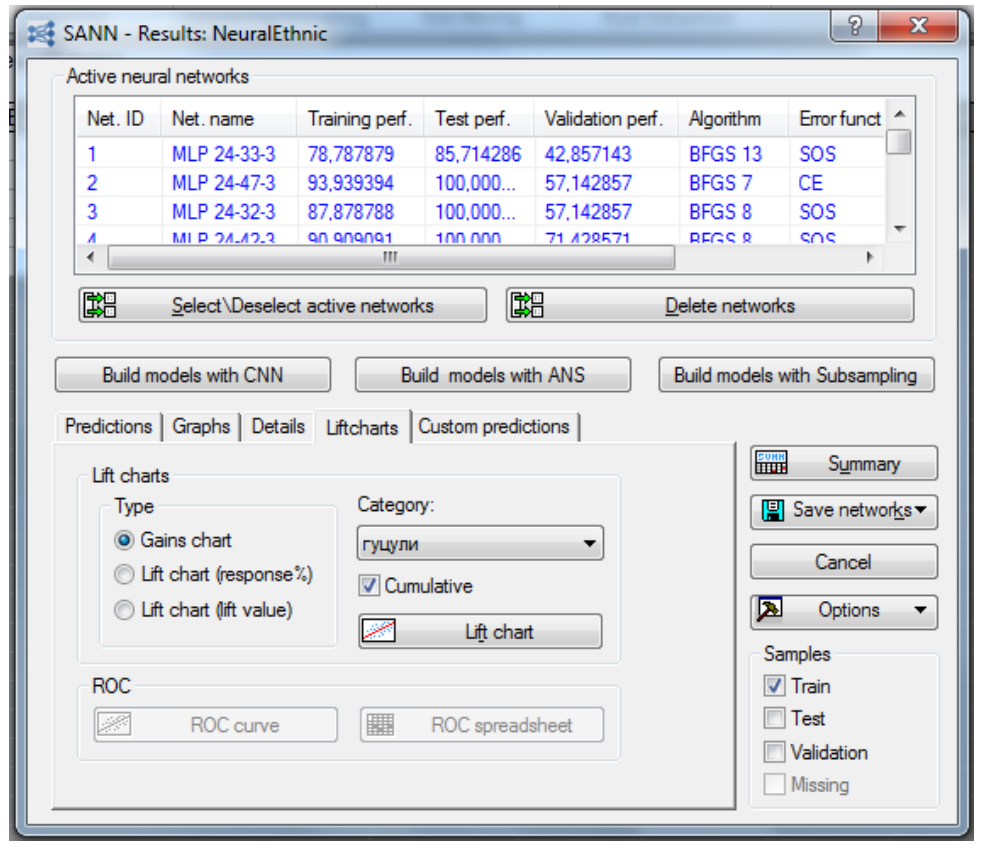

Fig. 2. A set of neural networks with different architectures and data performance of training

Step 4. Select the resulting network. For correct selection of the resulting network it is necessary also to pay attention not only to test performance, but to the matrix of errors (Fig. 3). 


\begin{tabular}{|c|c|c|c|c|c|}
\hline & \multicolumn{5}{|c|}{$\begin{array}{l}\text { ETHNIC (Classification summary) (NeuralEthnic) } \\
\text { Samples: Train }\end{array}$} \\
\hline & & ETHNIC-6ойки & ETHNIC-гуцули & ETHNIC-лемки & ETHNIC-All \\
\hline \multirow[t]{5}{*}{ 10.MLP 24-42-3 } & Totall & 14,00000 & 15,00000 & 4,0000 & 33,00000 \\
\hline & $\overline{\text { Correct }}$ & 13,00000 & 14,00000 & 4,0000 & 31,00000 \\
\hline & Incorrect & 1,00000 & 1,00000 & 0,0000 & 2,00000 \\
\hline & Correct (\%) & 92,85714 & 93,33333 & 100,0000 & 93,93939 \\
\hline & Incorrect (\%) & 7,14286 & 6,66667 & 0,0000 & 6,06061 \\
\hline
\end{tabular}

Fig. 3. Matrix of the errors for the network number 30

The analysis of obtained neural network includes building of confidence level (confidence levels) in all samples. As you can see, the red shows the incorrect prediction of belonging to a certain category (Fig. 4).

\begin{tabular}{|c|c|c|c|c|c|c|c|c|c|c|c|c|c|}
\hline \multirow[b]{2}{*}{$\begin{array}{l}\text { Case } \\
\text { name }\end{array}$} & \multicolumn{13}{|c|}{$\begin{array}{l}\text { Confidence levels (NeuralEthnic) } \\
\text { Samples: Train }\end{array}$} \\
\hline & \begin{tabular}{|c|} 
Cdl \\
Input
\end{tabular} & \begin{tabular}{l|} 
Atdr \\
Input
\end{tabular} & \begin{tabular}{c|} 
Adtr \\
Input
\end{tabular} & $\begin{array}{l}\text { Atbr } \\
\text { Input }\end{array}$ & $\begin{array}{l}\text { Btcr } \\
\text { Input }\end{array}$ & $\begin{array}{c}\text { Abr } \\
\text { Input }\end{array}$ & $\begin{array}{c}\text { Bcr } \\
\text { Input }\end{array}$ & \begin{tabular}{c|} 
Cdr \\
Input
\end{tabular} & $\begin{array}{c}\text { ETHNIC } \\
\text { Target }\end{array}$ & $\begin{array}{l}\text { ETHNIC - Output } \\
10 . M L P ~ 24-42-3\end{array}$ & $\begin{array}{l}\text { ETHNIC-бойки } \\
\text { 10.MLP 24-42-3 }\end{array}$ & $\begin{array}{l}\text { ETHNIC-гуцули } \\
\text { 10.MLP 24-42-3 }\end{array}$ & $\begin{array}{l}\text { ETHNIC-пемки } \\
\text { 10.MLP 24-42-3 }\end{array}$ \\
\hline 1 & 20,00000 & 83,00000 & 73,00000 & 62,00000 & 54,00000 & 13,00000 & 10,00000 & 17,00000 & бойки & бойки & 0,607221 & 0,245590 & 0,147189 \\
\hline 2 & 20,00000 & 77,00000 & 64,00000 & 53,00000 & 42,00000 & 12,00000 & 11,00000 & 18,00000 & гуцули[ & бойки & 0,455952 & 0,335452 & 0,208596 \\
\hline 4 & 19,00000 & 77,00000 & 63,00000 & 54,00000 & 42,00000 & 12,00000 & 10,00000 & 18,00000 & бойки & бойки & 0,529474 & 0,227835 & 0,242691 \\
\hline 7 & 18,00000 & 79,00000 & 74,00000 & 55,00000 & 47,00000 & 13,00000 & 12,00000 & 14,00000 & бойки & бойки & 0,421107 & 0,236206 & 0,342687 \\
\hline 10 & 23,00000 & 70,00000 & 68,00000 & 56,00000 & 42,00000 & 14,00000 & 11,00000 & 22,00000 & бойки & бойки & 0.411654 & 0,234265 & 0,354081 \\
\hline 11 & 22,00000 & 82,00000 & 74,00000 & 58,00000 & 44,00000 & 13,00000 & 10,00000 & 19,00000 & бойки & бойки & 0,423279 & 0,396416 & 0,180304 \\
\hline 12 & 19,00000 & 81,00000 & 72,00000 & 56,00000 & 48,00000 & 16,00000 & 11,00000 & 20,00000 & бойки & бойки & 0,432176 & 0,328808 & 0,239015 \\
\hline 13 & 21,00000 & 81,00000 & 73,00000 & 62,00000 & 52,00000 & 13,00000 & 11,00000 & 17,00000 & бойки & бойки & 0,593429 & 0,159428 & 0,247142 \\
\hline 14 & 19,00000 & 73,00000 & 52,00000 & 51,00000 & 40,00000 & 14,00000 & 12,00000 & 18,00000 & бойки & бойки & 0,404288 & 0,307658 & 0,288054 \\
\hline 16 & 24,00000 & 70,00000 & 69,00000 & 52,00000 & 41,00000 & 17,00000 & 14,00000 & 23,00000 & гуцули & гуцули & 0,237806 & 0,530996 & 0,231198 \\
\hline 19 & 25,00000 & 87,00000 & 78,00000 & 54,00000 & 40,00000 & 18,00000 & 11,00000 & 24,00000 & гуцули & гуцули & 0,232275 & 0,559756 & 0,207969 \\
\hline 21 & 24,00000 & 80,00000 & 72,00000 & 51,00000 & 42,00000 & 18,00000 & 10,00000 & 20,00000 & гуцули & гуцули & 0,264300 & 0,533540 & 0,202159 \\
\hline 23 & 26,00000 & 73,00000 & 70,00000 & 50,00000 & 40,00000 & 16,00000 & 13,00000 & 24,00000 & гуцули & гуцули & 0,188162 & 0,575445 & 0,236392 \\
\hline 24 & 24,00000 & 95,00000 & 90,00000 & 50,00000 & 30,00000 & 19,00000 & 14,00000 & 22,00000 & гуцули & гуцули & 0,224524 & 0,573174 & 0,202302 \\
\hline 25 & 23,00000 & 90,00000 & 70,00000 & 53,00000 & 40,00000 & 16,00000 & 19,00000 & 21,00000 & гуцули & гуцули & 0,138158 & 0,505010 & 0,356832 \\
\hline 26 & 22,00000 & 85,00000 & 70,00000 & 55,00000 & 43,00000 & 17,00000 & 17,00000 & 23,00000 & гуцули & гуцули & 0,224853 & 0,562917 & 0,212230 \\
\hline 27 & 22,00000 & 80,00000 & 70,00000 & 55,00000 & 42,00000 & 17,00000 & 14,00000 & 22,00000 & гуцули & гуцули & 0,297976 & 0,494631 & 0,207394 \\
\hline 28 & 24,00000 & 80,00000 & 69,00000 & 54,00000 & 42,00000 & 16,00000 & 14,00000 & 24,00000 & гуцули & гуцули & 0,234053 & 0,541870 & 0,224077 \\
\hline 29 & 22,00000 & 80,00000 & 52,00000 & 42,00000 & 41,00000 & 16,00000 & 13,00000 & 23,00000 & гуцули & гуцули & 0,187453 & 0,569456 & 0,243091 \\
\hline 30 & 23,00000 & 75,00000 & 50,00000 & 40,00000 & 35,00000 & 14,00000 & 15,00000 & 25,00000 & гуцули & гуцули & 0,216676 & 0,558267 & 0,225057 \\
\hline 31 & 13,00000 & 85,00000 & 65,00000 & 45,00000 & 35,00000 & 13,00000 & 16,00000 & 22,00000 & гуцули & гуцули & 0,234668 & 0,530664 & 0,234668 \\
\hline 32 & 12,00000 & 85,00000 & 70,00000 & 55,00000 & 35,00000 & 12,00000 & 15,00000 & 21,00000 & гуцули & гуцули & 0,250304 & 0,499791 & 0,249906 \\
\hline 34 & 22,00000 & 82,00000 & 74,00000 & 53,00000 & 49,00000 & 10,00000 & 17,00000 & 20,00000 & пемки & пемки & 0,168150 & 0,216334 & 0,615516 \\
\hline 35 & 23,00000 & 69,00000 & 73,00000 & 50,00000 & 42,00000 & 14,00000 & 13,00000 & 23,00000 & лемки & лемки & 0,217601 & 0,204521 & 0,577878 \\
\hline 36 & 23,00000 & 73,00000 & 71,00000 & 50,00000 & 43,00000 & 12,00000 & 14,00000 & 22,00000 & лемки & пемки & 0,212075 & 0,244610 & 0,543314 \\
\hline 38 & 19,00000 & 80,00000 & 69,00000 & 56,00000 & 43,00000 & 16,00000 & 10,00000 & 16,00000 & лемки & пемки & 0,257170 & 0,220471 & 0,522359 \\
\hline
\end{tabular}

Fig. 4. Confidence level of the neural network No. 10

Also pay attention to the analysis of importance (sensitivity analysis) of variables that are the part of the neural network (Fig. 5). The data of analysis will show that sign Wr one parameter is more important in predicting than other parameters. That is, the further analysis when debugging the model should pay attention to a sign Wr.

\begin{tabular}{|c|c|c|c|c|c|c|c|c|c|c|}
\hline \multirow[b]{2}{*}{ Networks } & \multicolumn{10}{|c|}{$\begin{array}{l}\text { Sensitivity analysis (NeuralEthnic) } \\
\text { Samples: Train }\end{array}$} \\
\hline & \begin{tabular}{|l|}
$\mathrm{Wr}$ \\
\end{tabular} & Adtl & LRr & LUI & LWI & Atdl & $\mathrm{Bcr}$ & Cdl & $\mathrm{Ar}$ & Atbr \\
\hline 10.MLP $24-42-3$ & 1,199798 & 1,188453 & 1,117243 & 1,086585 & 1,057846 & 1,046236 & 1,043343 & 1,042883 & 1,042469 & 1,038796 \\
\hline
\end{tabular}

Fig. 5. Analysis of importance (sensitivity analysis) of the input variables

Many data about the quality classification of the network can get on the lift card (Liftcharts) and various schedules, which makes it possible to build a software package STATISTICA.

\section{Discussion}

As result of research it was carried the prediction of anthropometric and antroposcopic parameters (ethno-territorial and gender belonging, etc.) through the use of dermatoglyphics parameters of the hands and feet into 180 people living in the Ivano-Frankivsk region.The proposed method allowed to obtain the results with a forecasts probability $73-90 \%$. The use of above algorithm of actions allowed a $50 \%$ increase of quality of identification of unknown person for using 
dermatoglyphic method and $67 \%$ facilitatation of the process of identification (of quantitative and qualitative calculations, determining correlations between parameters) in comparison with previously known manner. Therefore, our proposed method can be used as an express diagnostics of common phenotypic traits of the person (ethno-territorial affiliation, gender, etc.) at admission of mass victims (natural disasters, acts of terrorism, armed conflicts, man-made disasters, etc.), it doesn't not require a long time for conducting, specially trained staff and is inexpensive.

According to Mazur E. S. (2009), proposed new methods for diagnosing constitutional status (gender and type of body proportion), allow to diagnose these indicators with an accuracy of $87.0 \%$ and $91.0 \%$, respectively. The interrelationships between dermatoglyphic signs and external identification indicators of a person with allowance for sexual dimorphism have been established, on which basis the models for their diagnosis by the logitech regression method in a stepwise version have been developed. As a result, 22 diagnostic models for men and 7 for women have been developed. The accuracy of correct classification was from $65.0 \%$ to $98.0 \%$.

\section{Conclusions}

1. The possibility of predicting external-recognizing features of the person such as ethnoracial belonging, sex, anthropometric and antroposcopic parameters will allow widely use dermatoglyphic method at the level with other methods in conducting forensic identification of impersonal, fragmented and putrefactive modified corpses.

2. The proposed method allowed to obtain the results with a forecasts probability $73-90 \%$.

3. Using the above algorithm of actions allowed a $50 \%$ increase of quality identification of unknown person for using dermatoglyphic method and $67 \%$ facilitation of the process of identification.

4. Proposed method can be used as an express diagnostics of common phenotypic traits of a person at admission of mass victims.

\section{References}

[1] Shcherbakov, V. V., Shcherbakova, E. V. (2012). Personality identification based on the outcomes of mass casualty events. Forensic medical examination, 55 (1), 52-55.

[2] Bozhchenko, A. (2009). Forensic examination of dermatoglyphics of finger signs during identification. Saint Petersburg, 301.

[3] Bozhchenko, A. P., Tolmachev, I. A., Moiseenko, S. A., Kolkutin, V. V., Rakitin, B. A. (2009). Opportunities and prospects of forensic dermatoglyphics. Forensic medical examination, 52 (4), 33-36.

[4] Fandeeva, O. (2002). The study the dermatoglyphics signs of the toes as a characteristic of the genetic connection with respect to forensic expert identification. Moscow.

[5] Fandeeva, O. (2010). Structural organization of papillary finger's patterns, especially in family groups. Saint Petersburg, 431.

[6] Fandeev, A. (2005). Examination of relationships based on dermatoglyphs of the hand and feet. Moscow, 208.

[7] Sergienko, L. (2008). Dermatoglyphic markers in genetic prediction of phenotypic manifestations of psychomotor abilities. Theory and methods of physical education, 5, 11-17.

[8] Fokin, V. A., Ilyinskikh, N. N., Chantsev, A. V., Kozlov, Yu. A. (2002). The experience of creating a computer dactyloscopic program of medicogenetic destination. Bulletin of the Siberian medicine, 1, 117-120.

[9] Azazy, A. (2011). The image processing system in the diagnosis of hereditary diseases using the method dermatoglyphics. Tver, 16.

[10] Haykin, S. (1998). Neural Networks: A Comprehensive Foundation. Upper Saddle River: Prentice Hall, 842.

[11] Haykin, S. (2009). Neural networks and learning machines. Upper Saddle River: Pearson, 938.

[12] Specht, D. F. (1990). Probabilistic neural networks. Neural Networks, 3 (1), 109-118. doi: 10.1016/0893-6080(90)90049-q

[13] Wosserman, F. (1992). Neurocomputer equipment: theory and practice. Moscow, 184.

[14] Artificial neural network. Wikipedia. Available at: https://en.wikipedia.org/wiki/Artificial_neural_network

[15] Nielsen, M. (2017). Neural Networks and Deep Learning. Available at: http://neuralnetworksanddeeplearning.com 
[16] Guseva, I. (1986). Morphogenesis and genetics of whooping cough. Minsk.

[17] Tehako, L., Zelenkov, A. I. (2011). Social anthropology. Minsk, 224.

[18] Cohen, J., Cohen, P., West, S. G., Aiken, L. S. (2002). Applied multiple regression/correlation analysis for the behavioral sciences. Mahwah: L. Erlbaum, 219-220. doi: 10.4324/9780203774441

[19] Lachenbruch, P. A., Goldstein, M. (1979). Discriminant Analysis. Biometrics, 35 (1), 69. doi: $10.2307 / 2529937$

[20] STATISTICA Base. Statsoft. Available at: http://statsoft.ru/products/STATISTICA Base

[21] Coad, D. S., Everitt, B. S., Dunn, G. (1993). Applied Multivariate Data Analysis. The Statistician, 42 (3), 325-326. doi: 10.2307/2348816

\title{
THE STRUCTURAL FEATURES OF VASCULAR ENDOTHELIUM IN ACUTE CEREBRAL ISCHEMIA
}

\author{
Anna Kosheleva \\ Department of medical rehabilitation, sport medicine and physical rehabilitation \\ Kharkiv medical academy of postgraduate education \\ 58 Amosova str., Kharkiv, Ukraine, 61176 \\ anaz1@rambler.ru
}

\begin{abstract}
The aim of the research was to study the number and structural properties of desquamated endothelial cells (DECs) in the peripheral blood in carotid ischemic stroke (CIS) and carotid transient ischemic attacks (TIAs) and its connection with the marker of endothelial dysfunction - endothelin-1.

We examined 35 patients with the first CIS, on days 1st and 10th, and also 34 patients with symptomatic carotid TIAs, on days 1 st and 10th of the observation. Middle age of the examined patients with a CIS was $63,7 \pm 1,0$. Middle age of the examined patients with the TIAs was $54,7 \pm 1,0.25$ practically healthy persons were examined as a group of control. Neurologic deficit was assessed with the National Institutes of Health Stroke Scale (NIHSS). DECs were estimated by CD34 immunobead capture in the peripheral venous blood of patients and persons of control group. We studied the level of endothelin-1 in the peripheral venous blood of patients and persons of control group using the enzyme immunoassay using the Biomedica (Austria) during the first 24 hrs and on day 10. Statistical processing of the obtained results was carried out using statistical analysis package Statistica. In this case, the mean value, the standard error and the correlation analysis were determined. Samples were compared using the Student's criterion ( $t$ ) and the correlation coefficient (r).

During an examination of 35 patients in the acute period of CIS and 34 patients with carotid TIAs using the immunocytochemical method the number of DECs was studied in venous blood. The quantitative analysis of vascular endothelium in acute cerebral ischemias showed its statistically unreliable differences in CIS and TIAs.

A conclusion is drawn about the general mechanisms of endothelial dysfunction in CIS and TIAs. The number of DECs significantly correlates with the terms of disease. Regress of this indicator is noted in patients by the end of follow-up in both observation groups. During the first $24 \mathrm{hrs}$ in patients with CIS and TIAs density of DECs of blood directly correlates with the level of endothelin-1 blood. The endothelin-1 level tends to decrease by the 10th day of observation and the correlation force with the DECs level is correspondingly reduced.
\end{abstract}

Keywords: carotid ischemic stroke, transient ischemic attack, endothelium, desquamated endothelial cells, endothelin-1.

\section{Introduction}

Cardiovascular diseases are the number one cause of death worldwide [1]. The problem of cerebrovascular pathology and its consequences is the leading one for assessing the health status of the population in Ukraine [2]. Severe medical and social consequences of stroke are reflected in the indicators of disability of the population. In this regard, great importance is attached to the study of the pathophysiology of acute cerebral ischemia and the development of effective methods for correcting the revealed changes [3]. 